\title{
KERNICTERUS AND PREMATURITY
}

\author{
BY \\ V. M. CROSSE, T. C. MEYER and J. W. GERRARD \\ From Sorrento Maternity Hospital, Birmingham
}

(RECEIVED FOR PUBLICATION JUNE 30, 1955)

\begin{abstract}
At one time kernicterus was most commonly associated with haemolytic disease of the newborn. With the introduction of adequate exchange transfusions this complication, whether due to $\mathrm{Rh}$ or to ABO incompatibility, has been virtually eliminated. In 1950 two groups of workers, Aidin, Corner and Tovey in this country and Zuelzer and Mudgett in America, independently drew attention to the fact that kernicterus was sometimes associated with prematurity only. Other workers (Gerrard, 1952; Govan and Scott, 1953) have also given details of cases and suggested possible aetiological factors.

The present paper draws attention to the early signs of the disease, its mortality and the sequelae in survivors. An attempt has also been made to assess its incidence, its relationship to such factors as sex, birth weight, maturity and birth order, and ante-natal and post-natal factors. Among the post-natal factors specifically studied has been the level of the serum bilirubin in those developing kernicterus; these levels have been compared with those in normals.
\end{abstract}

\section{Material and Methods}

Three groups of babies have been studied. First, 60 premature babies in three Birmingham units who developed kernicterus in the absence of iso-immunization during the years 1951-54. Kernicterus was demonstrated either at necropsy in those who died in the neonatal period or by follow-up studies in the survivors. These cases have been compared first with 60 controls (a control was the first baby in the same $500 \mathrm{~g}$. weight group admitted to the same premature baby unit after the case developing kernicterus), secondly, when possible, with all the premature babies $(2,608)$ admitted to the units during the same period.

A second group of 91 children has been studied to assess the importance, if any, of blood group incompatibility between the mother and child. This group was composed of 56 dying in the neonatal period, in which the diagnosis was confirmed at necropsy, and of 35 who survived with varying degrees of choreoathetosis and perceptive deafness. The latter had all been deeply jaundiced in infancy, and their history was characteristic of kernicterus as seen in prematures. This group included the 60 cases already mentioned. Iso-immunization was excluded by a negative direct Coombs test on the baby's blood in 59 instances; by the absence of any anomalous agglutinins and of immune anti-A and anti-B in the maternal serum in 83; and by a negative indirect Coombs test, using maternal serum and either the infant's or the father's red cells, in 50.

A third group of cases has been studied to determine whether there is any relationship between the degree of jaundice and the development of kernicterus. This group included 46 normal full-term and 47 premature babies. The serum bilirubin was estimated on the second, fourth and sixth days. The mean serum bilirubin levels in babies of different birth weight groups were then calculated. Twelve premature babies who developed kernicterus in the absence of iso-immunization were also studied; these 12 were all included in the first group of 60 . The total, direct and indirect, serum bilirubin levels were estimated on venous blood by the method of Malloy and Evelyn (1937).

\section{Results}

The following results are based on our findings in the first group of prematures.

The Signs of Kernicterus. The first 24 or $\mathbf{4 8}$ hours of life in the premature baby are the most critical, but once these are passed the chances of ultimate survival are good. The signs of kernicterus (Table 1) develop in a baby who is jaundiced after this initial adjustment to an extra-uterine environment. The signs include head retraction, an expressionless facies, usually with oculogyric movements, changes in muscle tone, cyanotic attacks, a refusal to suck in those bottle-fed, vomiting and, terminally, haemorrhage, usually from the mouth.

In severe cases these signs are self evident, but in those less affected they are easily missed. Jaundice may be overlooked, especially in artificial light, because the plethoric colour of prematures tends to conceal the underlying icterus. If the skin, however, is stretched between two fingers, jaundice becomes immediately apparent. Oculogyric move- 
TABLE 1

SIGNS OF KERNICTERUS

\begin{tabular}{|c|c|c|}
\hline & \multicolumn{2}{|c|}{ Number of Babies Showing Sign } \\
\hline & Kernicterus (60) & Controls (60) \\
\hline 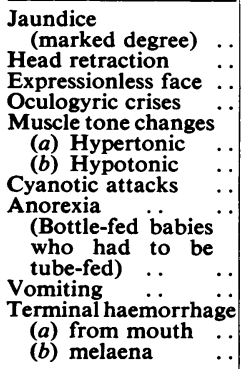 & $\begin{array}{r}38 \\
38 \\
\text { approx. } 40 \\
\text { approx. } 40 \\
31 \\
19 \\
12 \\
34 \\
30 \\
\\
\text { of } 46 \text { bottle fed } \\
31 \\
8 \\
7 \\
1\end{array}$ & $\begin{array}{l}2 \\
= \\
= \\
\overline{1} \\
5 \\
\text { of } 38 \text { bottle fed } \\
= \\
=\end{array}$ \\
\hline
\end{tabular}

ments of the eyes are also characteristic, but they may not be noticed unless specifically sought; the eyes tend to roll down and give a 'setting sun' appearance. A baby who exhibits any of the signs enumerated above, especially between the fourth and eighth days of life, is re-examined at regular intervals by us for at least one year, even if he appears normal on discharge. Several babies who showed minimal signs have proved to be definite cases of kernicterus.

The Time of Onset of Kernicterus. All but four of the 60 cases developed kernicterus between the fourth and eighth days of life; in nearly half the onset was on the sixth day (Table 2). In the $1,000-1,500 \mathrm{~g}$. weight group more cases occurred before the sixth day than after; in the $1,500-2,000 \mathrm{~g}$. weight group equal numbers occurred before and after this day; in the heaviest weight group, 2,0002,500 g., more cases occurred after the sixth day than before. The onset tended to be later as the birth weight increased.

Neonatal Mortality and Kernicterus. During the period under study, $17 \%$ of the controls and $25.6 \%$ of all premature babies admitted, died, but of the 60 cases of kernicterus, $73 \%(44)$ died. With the exception of the 2,000-2,500 g. group, the mortality from kernicterus decreased as birth weight increased (Table 3). The high mortality in the $2,000-2,500 \mathrm{~g}$.

TABLE 3

NEONATAL MORTALITY AND KERNICTERUS

\begin{tabular}{|c|c|c|c|c|c|}
\hline \multirow{3}{*}{$\begin{array}{c}\text { Weight } \\
\text { (g.) }\end{array}$} & & \multicolumn{2}{|c|}{ Kernicterus } & \multicolumn{2}{|c|}{$\begin{array}{l}\text { All Prematures } \\
\text { Admitted }\end{array}$} \\
\hline & \multicolumn{3}{|c|}{ Neonatal Death } & \multicolumn{2}{|c|}{ Neonatal Death } \\
\hline & & Total & No. & Total & No. \\
\hline $\begin{array}{l}\text { Up to } 1,000 \\
1,000 \text { to } 1,500 \\
1,500 \text { to } 2,000 \\
2,000 \text { to } 2,500\end{array}$ & $\because$ & $\begin{array}{r}3 \\
18 \\
24 \\
15\end{array}$ & $\begin{array}{l}3(100 \%) \\
16 \quad(89 \%) \\
13(54 \%) \\
12(81 \%)\end{array}$ & $\begin{array}{r}120 \\
405 \\
1,123 \\
960\end{array}$ & $\begin{array}{l}104(87 \%) \\
206(51 \%) \\
236(21 \%) \\
122(12.7 \%)\end{array}$ \\
\hline Total & .. & 60 & $44 \quad(73 \%)$ & 2,608 & $668(25 \cdot 6 \%)$ \\
\hline
\end{tabular}

* Babies weighing over $2,000 \mathrm{~g}$. are only admitted if ill and this accounts for the high mortality in this weight group.

group is probably due to the fact that babies over $2,000 \mathrm{~g}$. are only admitted if in poor condition.

Generally speaking, the earlier the onset, the higher the mortality, but this may be accounted for by the earlier onset among the smallest babies (Table 2).

Sequelae in Survivors. Sixteen of the 60 cases of kernicterus survived the neonatal period. The majority were hypotonic in the neonatal period, while a few remained hypertonic and lay with the head thrown back. A few weeks later all appeared to be normal.

Follow-up examinations were carried out at the 'corrected ages' of 6,12 and 18 months, the 'corrected age' being the chronological age plus the number of weeks that the child was born before the expected date of delivery.

At 6 Months. All babies were re-examined at this age. The majority were irritable, did not sleep well and cried a great deal. Twelve had spells of opisthotonos, 10 exhibited some degree of

TABLE 2

DAY OF ONSET OF KERNICTERUS

\begin{tabular}{|c|c|c|c|c|c|}
\hline \multirow{2}{*}{ Day of Life } & \multicolumn{5}{|c|}{ Birth Weight Groups } \\
\hline & Up to $1,000 \mathrm{~g}$. & $1,000-1,500 \mathrm{~g}$ & $1,500-2,000 \mathrm{~g}$ & $2,000-2,500 \mathrm{~g}$ & Total \\
\hline $\begin{array}{r}3 \\
4 \\
5 \\
6 \\
7 \\
8 \\
9 \\
\text { After } 9\end{array}$ & $\begin{array}{l}1 \text { (died) } \\
1 \text { (died) } \\
1 \text { (died) } \\
-\end{array}$ & $\begin{array}{l}6(\overline{6} \text { died }) \\
8 \text { (6 died }) \\
3(3 \text { died }) \\
1 \text { (died })\end{array}$ & $\begin{array}{l}1 \text { (died) } \\
3 \text { (2 died) } \\
4 \text { (3 died) } \\
8 \text { (3 died }) \\
3 \text { (2 died) } \\
3 \text { (1 died) } \\
2 \text { (1 died) }\end{array}$ & $\begin{array}{c}1 \text { (died) } \\
11 \text { (9 died) } \\
1 \text { (died) } \\
2 \text { (1 died) } \\
\text { - }\end{array}$ & $\begin{array}{r}1 \text { (died) } \\
11 \text { (91\% died) } \\
4(75 \% \text { died) } \\
28(68 \% \text { died) } \\
7(86 \% \text { died }) \\
6(50 \% \text { died) } \\
2 \text { (50\% died) } \\
1 \text { (died) }\end{array}$ \\
\hline Total .. & 3 (3 died) & $18(89 \%$ died $)$ & $24(54 \%$ died $)$ & $15(81 \%$ died $)$ & $60(73 \%$ died $)$ \\
\hline
\end{tabular}


eye-rolling. All had been late in smiling, holding their heads up and taking solids. When lowered into the prone position, 13 still went into the kneechest position, and when in the prone position, with the hips extended and knees flexed, the babies still responded to stroking of the soles by hip flexion, i.e., by the withdrawal reflex. Muscle tone was variable.

At 12 Months. The three most severely affected babies died with severe rigidity and hyperpyrexia before reaching this age, and three have left the area. Of the remaining 10 babies, eight were less irritable and were sleeping better. Feeding difficulties were still present in five, opisthotonos in six and oculogyric movements in four. All were backward in reaching the recognized milestones: only two were able to sit without support, and only one could stand alone. Hearing was probably impaired in seven. Speech was delayed in all, and so was mental development.

At 18 Months. Six babies have now reached this age. These six appear contented. Five are definitely hypotonic, and in two of these athetoid movements are beginning to develop. Three still exhibit spells of opisthotonos and oculogyric movements. The withdrawal reflex is still present in four. Two can sit without support; one of these has good head control and can stand by himself. Speech is delayed in all, one can say recognizable words, and this is the only child whose hearing appears to be unimpaired. Mental development is delayed in all.

Dental Development. None of the children have green teeth. In only one are the canines fully erupted. In this the junction between the hypoplastic pre-natal and well calcified post-natal enamel can be clearly seen on the canines half way between the incisal edge and the gingival margin.

TABLE 4

KERNICTERUS AND BIRTH WEIGHT

\begin{tabular}{|c|c|c|c|c|c|c|}
\hline \multirow{2}{*}{$\begin{array}{l}\text { Birth } \\
\text { Weight } \\
\text { (g.) }\end{array}$} & & \multicolumn{2}{|c|}{$\begin{array}{c}\text { All } \\
\text { Prematures } \\
\text { Admitted }\end{array}$} & \multicolumn{3}{|c|}{ Kernicterus } \\
\hline & & Total & $\begin{array}{c}\text { Babies } \\
\text { at Risk } \\
\text { (48-hour } \\
\text { Sur- } \\
\text { vivors) }\end{array}$ & Total & $\begin{array}{c}\text { Percentage } \\
\text { of } \\
\text { Total }\end{array}$ & $\begin{array}{c}\text { Percentage } \\
\text { of Babies } \\
\text { at Risk }\end{array}$ \\
\hline $\begin{array}{l}\mathrm{Up} \text { to } 1,000 \\
1,000 \text { to } 1,500 \\
1,500 \text { to } 2,000 \\
2,000 \text { to } 2,500\end{array}$ & $\begin{array}{l}\cdots \\
\cdots \\
\cdots\end{array}$ & $\begin{array}{r}120 \\
405 \\
1,123 \\
960\end{array}$ & $\begin{array}{r}43 \\
266 \\
972 \\
900\end{array}$ & $\begin{array}{r}3 \\
18 \\
24 \\
15\end{array}$ & $\begin{array}{l}2 \cdot 5 \\
4 \cdot 4 \\
2 \cdot 1 \\
1 \cdot 6\end{array}$ & $\begin{array}{l}7 \cdot 0 \\
6 \cdot 8 \\
2 \cdot 5 \\
1 \cdot 7\end{array}$ \\
\hline Total & & 2,608 & 2,181 & 60 & $2 \cdot 3$ & $2 \cdot 8$ \\
\hline
\end{tabular}

Factors with a Bearing on Aetiology. Table 4 shows $(a)$ all prematures admitted during the fouryear period 1951-54, and (b) the 60 cases of kernicterus, divided into $500 \mathrm{~g}$. birth weight groups. With the exception of those weighing less than 1,000 g. at birth, the incidence of kernicterus decreased as the birth weight increased. Because many premature babies, especially those weighing less than $1,000 \mathrm{~g}$. at birth, die before they can develop kernicterus, the incidence of this complication is also determined among those surviving the first $\mathbf{4 8}$ hours; the incidence was highest in those weighing less than $1,000 \mathrm{~g}$. at birth. The incidence of kernicterus was, therefore, inversely proportional to the weight at birth among the babies at risk.

MATURITY. The relationship of kernicterus to maturity is shown in Table 5. The incidence of

TABLE 5

KERNICTERUS AND MATURITY

\begin{tabular}{|c|c|c|c|c|c|c|}
\hline \multirow{2}{*}{$\begin{array}{l}\text { Maturity } \\
\text { in Weeks }\end{array}$} & & \multicolumn{2}{|c|}{$\begin{array}{c}\text { All } \\
\text { Prematures } \\
\text { Admitted }\end{array}$} & \multicolumn{3}{|c|}{ Kernicterus } \\
\hline & & Total & $\begin{array}{c}\text { Babies at } \\
\text { Risk (48- } \\
\text { hour Sur- } \\
\text { vivors) }\end{array}$ & Cases & $\begin{array}{c}\text { Percentage } \\
\text { of } \\
\text { Total }\end{array}$ & $\begin{array}{c}\text { Percentage } \\
\text { of Babies } \\
\text { at Risk }\end{array}$ \\
\hline $\begin{array}{l}\text { Up to } 30 \\
31 \text { to } 32 \ldots \\
33 \text { to } 34 \ldots \\
35 \text { to } 36 \ldots \\
\text { Over } 36 \ldots\end{array}$ & $\begin{array}{l}\cdots \\
\cdots \\
\cdots \\
\cdots\end{array}$ & $\begin{array}{l}264 \\
386 \\
801 \\
792 \\
365\end{array}$ & $\begin{array}{l}109 \\
282 \\
685 \\
749 \\
356\end{array}$ & $\begin{array}{r}11 \\
16 \\
22 \\
8 \\
3\end{array}$ & $\begin{array}{l}4 \cdot 2 \\
4 \cdot 2 \\
2 \cdot 7 \\
1 \cdot 0 \\
0 \cdot 8\end{array}$ & $\begin{array}{r}10 \cdot 1 \\
5 \cdot 7 \\
3 \cdot 2 \\
1 \cdot 1 \\
0 \cdot 8\end{array}$ \\
\hline Total & . & 2,608 & 2,181 & 60 & $2 \cdot 3$ & $2 \cdot 8$ \\
\hline
\end{tabular}

kernicterus was inversely proportional to maturity both for all prematures and for those surviving the first two days.

BIRTH ORDER. When the cases of kernicterus are compared with the 60 controls and with all the premature babies admitted during the same fouryear period (Table 6), it is seen that there is no appreciable difference between the three series in regard to the percentage found in each birth rank.

TABLE 6

KERNICTERUS AND BIRTH ORDER

\begin{tabular}{|c|c|c|c|c|c|c|}
\hline \multirow{2}{*}{$\begin{array}{l}\text { Birth } \\
\text { Order }\end{array}$} & \multicolumn{2}{|c|}{ Kernicterus } & \multicolumn{2}{|c|}{ Controls } & \multicolumn{2}{|c|}{$\begin{array}{c}\text { All } \\
\text { Prematures } \\
\text { Admitted }\end{array}$} \\
\hline & Total & Percentage & Total & Percentage & Total & Percentage \\
\hline $\begin{array}{l}1 \\
2 \\
3 \\
4 \\
5 \\
6+\end{array}$ & $\begin{array}{r}20 \\
13 \\
10 \\
8 \\
3 \\
6\end{array}$ & $\begin{array}{r}33 \cdot 3 \\
21 \cdot 7 \\
16 \cdot 7 \\
13 \cdot 3 \\
5 \cdot 0 \\
10 \cdot 0\end{array}$ & $\begin{array}{r}19 \\
15 \\
9 \\
8 \\
5 \\
4\end{array}$ & $\begin{array}{r}31 \cdot 7 \\
25 \cdot 0 \\
15 \cdot 0 \\
13 \cdot 3 \\
8 \cdot 3 \\
6 \cdot 7\end{array}$ & $\begin{array}{l}879 \\
725 \\
436 \\
175 \\
125 \\
268\end{array}$ & $\begin{array}{r}33 \cdot 7 \\
27 \cdot 8 \\
16 \cdot 7 \\
6 \cdot 7 \\
4 \cdot 8 \\
10 \cdot 3\end{array}$ \\
\hline Total . & 60 & $100 \cdot 0$ & 60 & $100 \cdot 0$ & 2,608 & $100 \cdot 0$ \\
\hline
\end{tabular}


It can be concluded, therefore, that birth rank does not have any influence on the development of kernicterus.

Sex. An excess of females is usual among prematures because, on average, females weigh less than males at each stage of gestation. As expected, therefore, there was a slight excess of females among the 60 controls; $55 \%$ were female. This was in very close agreement with the distribution among all prematures born in the City of Birmingham during the same four-year period, of whom $54.7 \%$ were female. Among the cases of kernicterus, however, there was a preponderance of males; only $42 \%$ were female.

Multiple Birth. Table 7 shows that there was no significant excess of multiple births among the

TABLE 7

KERNICTERUS AND MULTIPLE BIRTH

\begin{tabular}{|c|c|c|c|}
\hline & Kernicterus & Controls & $\begin{array}{c}\text { All } \\
\text { Prematures } \\
\text { Admitted }\end{array}$ \\
\hline $\begin{array}{l}\text { 1st born twin } \\
\text { 2nd born twin } \\
\text { Triplet } \quad \ldots\end{array}$ & $\begin{array}{l}4 \text { babies } \\
11 \text { babies } \\
-\end{array}$ & $\begin{array}{c}7 \text { babies } \\
6 \text { babies } \\
-\end{array}$ & $\begin{array}{r}273 \text { babies } \\
277 \text { babies } \\
27 \text { babies }\end{array}$ \\
\hline All multiple born & $15=25 \cdot 0 \%$ & $13=21 \cdot 7 \%$ & $577=22 \cdot 1 \%$ \\
\hline
\end{tabular}

affected babies. When a twin developed kernicterus, the second was more frequently affected than the first. This was not due to any marked difference in the weight of the baby, for the average birth weight of those affected was $1,600 \mathrm{~g}$., and of those unaffected was $1,650 \mathrm{~g}$. The sex distribution among affected cases was approximately equal, eight were male and seven female; four pairs were MM, three FF and seven MF. Only once did both twins develop kernicterus; one was male, the other was female.

Complications of Pregnancy. Table 8 shows the main complications of pregnancy for the cases of kernicterus, the controls and all admissions.

TABLE 8

COMPLICATIONS OF PREGNANCY

\begin{tabular}{|c|c|c|c|}
\hline & $\begin{array}{c}\text { Kernicterus } \\
(60)\end{array}$ & $\begin{array}{c}\text { Controls } \\
(60)\end{array}$ & $\begin{array}{c}\text { All Prematures } \\
\text { Admitted } \\
(2,608)\end{array}$ \\
\hline & Total & Total & Total \\
\hline $\begin{array}{l}\text { Toxaemia . } \\
\text { Non-toxic separa- } \\
\text { tion of placenta } \\
\text { Maternal illnesses } \\
\text { Other } \quad . \quad \ldots\end{array}$ & $\begin{aligned} 2 & (3 \cdot 3 \%) \\
11 & (18 \cdot 3 \%) \\
4 & (6 \cdot 7 \%) \\
5 & (8 \cdot 3 \%)\end{aligned}$ & $\begin{array}{ll}9 & (15 \cdot 0 \%) \\
5 & (8.4 \%) \\
2 & (3.3 \%) \\
4 & (6.7 \%)\end{array}$ & $\begin{array}{l}331(12.7 \%) \\
167(6.4 \%) \\
156(6.0 \%)\end{array}$ \\
\hline Totals & $22(36 \cdot 6 \%)$ & $20(33 \cdot 4 \%)$ & $1,118(42 \cdot 9 \%)$ \\
\hline
\end{tabular}

Toxaemia, perhaps the commonest known cause of prematurity, was only infrequently associated with kernicterus in the infant. Non-toxic separation of the placenta, on the other hand, occurred with rather unexpected frequency.

Complications of LABOur. Abnormalities of labour did not predispose to the development of kernicterus; the incidence of breech and forceps deliveries and other complications did not differ significantly in the three groups. It was not possible to assess accurately the incidence of asphyxia at birth, because the majority of the babies were delivered elsewhere, but a history of asphyxia was obtained in $28 \%$ (17) of the babies who developed kernicterus, and in $20 \%$ (12) of the controls.

Post-natal Complications. The complications listed in Table 9 were observed before any signs of

TABLE 9

POST-NATAL COMPLICATIONS

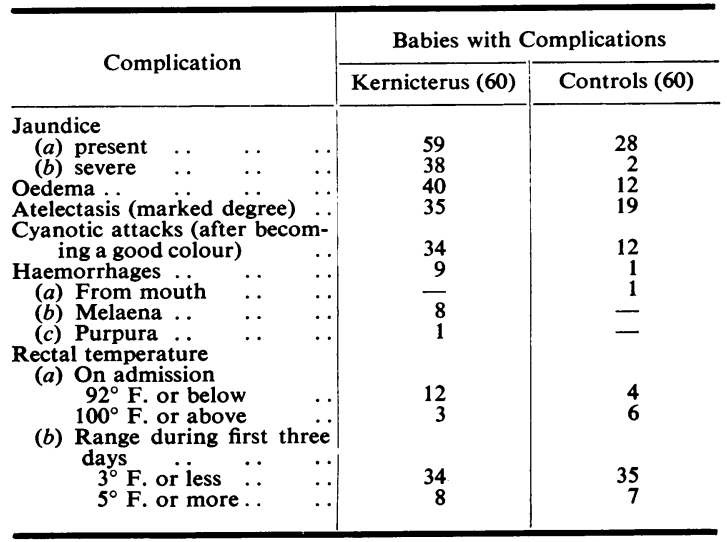

kernicterus had appeared. Jaundice, oedema, atelectasis, cyanotic attacks, haemorrhages and hypothermia on admission were all more frequently observed in those who later developed kernicterus than in the controls.

Post-natal Treatment. The following factors having a possible bearing on the incidence of kernicterus were examined: the period of starvation before feeds were introduced, the administration of oxygen, of sedatives, and of vitamin $B, C$ and $K$ (Table 10).

Period of Starvation. On average, feeds were introduced no later in the children who developed kernicterus than in the controls; the former were offered their first feeds after an average of $2 \cdot 1$, and the latter after an average of 2.0 days. Three children who developed kernicterus were, however, 
TABLE 10

POST-NATAL TREATMENT

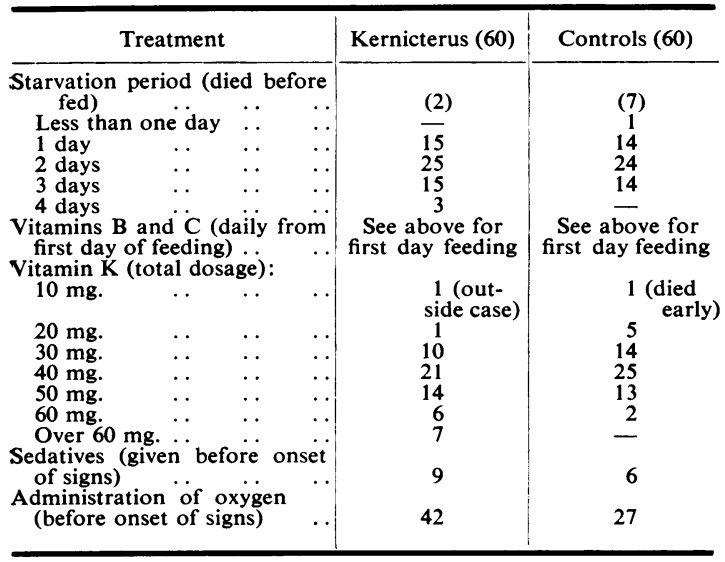

not given their first feed until the fourth day, a longer period of starvation than that experienced by any of the controls.

OXYGEN. Forty-two of the babies who developed kernicterus were given oxygen compared with only 27 of the controls. Oxygen is never given as routine treatment, but only when specifically indicated.

Sedatives. Before the onset of signs of kernicterus, nine affected babies and only six controls required sedatives (chloral or paraldehyde). Most babies who developed kernicterus had no sedation.

VITAMINS. The administration of vitamins B and $\mathrm{C}$ did not differ in the two groups. The administration of vitamin $\mathrm{K}$ did and was therefore studied in greater detail. All vitamin $\mathrm{K}$ was given in the form of 'synkavit'.

Only two of the controls, both fed late, were given more than $50 \mathrm{mg}$. of vitamin $\mathrm{K}$, whereas 13 of the babies who later developed kernicterus were given more than $50 \mathrm{mg}$. These 13 babies were given extra vitamin $\mathrm{K}$ for the following reasons: haemorrhagic diathesis (nine), suspected intracranial haemorrhage (two) and delay in the introduction of feeds (two).

To clarify the relationship between the administration of vitamin $\mathrm{K}$ and the development of kernicterus the yearly incidence of kernicterus in two of the units has been calculated for the period 1945-54 and has been correlated with the dosage scheme of vitamin $\mathrm{K}$ in use each year (Table 11). Until 1950 it was the practice in unit $S$ to give only one injection of vitamin $\mathrm{K}(1-10 \mathrm{mg}$.) on admission; after this date $10 \mathrm{mg}$. were given for the first three days of life. During 1953 and 1954 vitamin K was given eight hourly to babies with a tendency to bleed or with signs of increased intracranial pressure. With the increase in dose of vitamin $\mathrm{K}$, the incidence of kernicterus rose four-fold, from $1 \%$ to $4 \%$, approximately, of all admissions. In unit $\mathrm{C}$ it has been the practice, since 1950 , to give $10 \mathrm{mg}$. of vitamin daily until two days after the introduction of feeds. Babies in this unit have therefore been given, on average, $30-50 \mathrm{mg}$. of vitamin $\mathrm{K}$. 'The incidence of kernicterus in this unit $(2.8 \%)$ since 1950 has been slightly higher than in unit $S(2 \cdot 2 \%)$.

In the case of the twins, the twin receiving more vitamin $\mathrm{K}$ was more likely to develop kernicterus than the twin who received less. There were 11 pairs of twins in which both lived long enough to develop kernicterus. In only one instance did both develop kernicterus; both received $40 \mathrm{mg}$. of vita$\min \mathrm{K}$. Where dosage of vitamin $\mathrm{K}$ differed it was always the twin who received more vitamin $K$ who developed kernicterus, but in four instances both received the same dose of vitamin $K$ and yet only one developed kernicterus. On average, the kernicteric twin received $52 \mathrm{mg}$. of vitamin $\mathrm{K}$ (range 30-120 mg.) whereas the unaffected received $30 \mathrm{mg}$. (range $10-40 \mathrm{mg}$.). One affected baby received the unusually large dose of $120 \mathrm{mg}$. of vitamin $\mathrm{K}$; if this child and its twin are removed from the series

TABLE 11

KERNICTERUS AND VITAMIN K DOSAGE

\begin{tabular}{|c|c|c|c|c|c|c|c|c|}
\hline \multirow{3}{*}{ Year } & \multicolumn{4}{|c|}{ Unit $S$. } & \multicolumn{4}{|c|}{ Unit $C$. } \\
\hline & \multirow{2}{*}{$\begin{array}{l}\text { Vitamin K } \\
\text { (total mg.) }\end{array}$} & \multirow[b]{2}{*}{ Admissions } & \multicolumn{2}{|c|}{ Kernicterus } & \multirow{2}{*}{$\underset{\text { (total mg.) }}{\text { Vitamin K }}$} & \multirow[b]{2}{*}{ Admissions } & \multicolumn{2}{|c|}{ Kernicterus } \\
\hline & & & Total & $\%$ & & & Total & $\%$ \\
\hline $\begin{array}{l}1945 \\
1946 \\
1947 \\
1948 \\
1949 \\
1950 \\
1951 \\
1952 \\
1953 \\
1954\end{array}$ & $\begin{array}{c}1-2 \\
1-2 \\
1-2 \\
1-2 \\
10 \\
30 \\
30 \\
30 \\
30+ \\
30+\end{array}$ & $\begin{array}{l}215 \\
234 \\
254 \\
219 \\
243 \\
252 \\
269 \\
263 \\
316 \\
334\end{array}$ & $\begin{array}{r}2 \\
5 \\
2 \\
1 \\
4 \\
3 \\
3 \\
1 \\
13 \\
12\end{array}$ & $\begin{array}{l}0 \cdot 9 \\
2 \cdot 1 \\
0 \cdot 8 \\
0 \cdot 5 \\
1 \cdot 6 \\
1 \cdot 2 \\
1 \cdot 1 \\
0 \cdot 4 \\
4 \cdot 1 \\
3 \cdot 6\end{array}$ & $\begin{array}{l}1-5 \\
1-5 \\
30-50 \\
30-50 \\
30-50 \\
30-50 \\
30-50\end{array}$ & $\begin{array}{r}70 \\
141 \\
138 \\
164 \\
153 \\
146 \\
173\end{array}$ & $\begin{array}{l}0 \\
0 \\
4 \\
3 \\
6 \\
5 \\
4\end{array}$ & $\begin{array}{l}0 \\
0 \\
2 \cdot 9 \\
1 \cdot 8 \\
3 \cdot 9 \\
3 \cdot 4 \\
2 \cdot 3\end{array}$ \\
\hline
\end{tabular}


the kernicterus babies still received more vitamin $\mathrm{K}$ (average $44 \mathrm{mg}$., range $30-60 \mathrm{mg}$.) than the unaffected (average $31 \mathrm{mg}$., range 10-40 $\mathrm{mg}$.).

Blood Group Incompatibilities. The incidence of the $\mathbf{A}, \mathrm{B}, \mathrm{O}$ groups and the $\mathrm{C}, \mathrm{D}, \mathrm{E}, \mathrm{c}$ and $\mathrm{d}$ antigens were studied in the mother, father and child of the second group of patients. Data were not complete in every case, but they were in the majority. The distribution of the $A, B$ and $O$ groups is shown in Table 12. Although there is a

TABLE 12

KERNICTERUS AND ABO/DISTRIBUTION

\begin{tabular}{|c|c|c|c|c|}
\hline & \multicolumn{4}{|c|}{ Percentage Distribution of ABO Groups } \\
\hline & \multicolumn{3}{|c|}{ Parents and Kernicteric Child } & \multirow[b]{2}{*}{ Normal } \\
\hline & Father & Mother & Child & \\
\hline $\begin{array}{r}\mathbf{O} \\
\mathbf{A} \\
\mathbf{B} \\
\mathbf{A B}\end{array}$ & $\begin{array}{l}44 \\
50 \\
4 \cdot 5 \\
1 \cdot 5\end{array}$ & $\begin{array}{l}50 \\
39 \cdot 5 \\
7 \\
3 \cdot 5\end{array}$ & $\begin{array}{l}46 \\
45 \\
6 \cdot 5 \\
2 \cdot 5\end{array}$ & $\begin{array}{r}44 \cdot 3 \\
42 \cdot 8 \\
9 \cdot 1 \\
3 \cdot 7\end{array}$ \\
\hline Cases & 68 & 86 & 76 & \\
\hline
\end{tabular}

slight, but not significant, excess of group $\mathrm{O}$ among the mothers, there is no appreciable diminution of group $\mathbf{O}$ among either the fathers or the affected children. Not all the affected children were less than $2,500 \mathrm{~g}$. at birth, and were, therefore, not strictly speaking, premature, but if the 15 who weighed more than $2,500 \mathrm{~g}$. at birth are removed from the series, the distribution of the $A B O$ group is not materially altered. It is concluded that $\mathrm{ABO}$ incompatibility did not play a significant part in the production of kernicterus in this group.

It was considered unlikely that the less antigenic $\mathrm{Rh}$ antigens would predispose to the development of kernicterus in these cases; nevertheless, the distribution in the parents and children of the $D, d d$, $\mathrm{C}$, c and $\mathrm{E}$ antigens was investigated (Table 13). The distribution did not differ from the expected

TABLE 13

KERNICTERUS AND DISTRIBUTION OF RH FACTORS

\begin{tabular}{|c|c|c|c|c|}
\hline & \multicolumn{4}{|c|}{$\begin{array}{l}\text { Percentage Distribution of } \\
\text { D, dd, C, E, and c Factors }\end{array}$} \\
\hline & \multicolumn{3}{|c|}{ Parents and Kernicteric Child } & \multirow[b]{2}{*}{ Normal } \\
\hline & Father & Mother & Child & \\
\hline $\begin{array}{c}\mathbf{D} \\
\mathbf{d d} \\
\mathbf{C} \\
\mathbf{E} \\
\mathrm{c}\end{array}$ & $\begin{array}{l}83 \\
17 \\
71 \\
30 \cdot 7 \\
72 \cdot 5\end{array}$ & $\begin{array}{l}85 \\
15 \\
70 \cdot 8 \\
29 \cdot 2 \\
72 \cdot 3\end{array}$ & $\begin{array}{l}80 \\
20 \\
61 \\
26 \\
85\end{array}$ & $\begin{array}{l}85 \\
15 \\
67 \cdot 8 \\
27 \cdot 7 \\
81 \cdot 4\end{array}$ \\
\hline Cases & 62 & 72 & 54 & \\
\hline
\end{tabular}

to any significant degree. It is concluded that these factors played no part in producing kernicterus.

Bilirubin Levels in Babies with Kernicterus and in Normal Full-term and Premature Babies. *Bilirubin levels were studied in 12 babies who developed kernicterus; in 10 the levels rose above $18 \mathrm{mg}$. per $100 \mathrm{ml}$. and in two they did not; these two were moribund when the estimations were made, and the levels may not indicate the heights to which the serum bilirubin had risen when kernicterus developed.

Serum bilirubin levels were also studied in 46 fullterm and in 47 premature babies so that a clearer understanding of the levels in unaffected babies might be obtained (Fig. 1). In none did the serum bilirubin rise above $18 \mathrm{mg}$. per $100 \mathrm{ml}$. It is

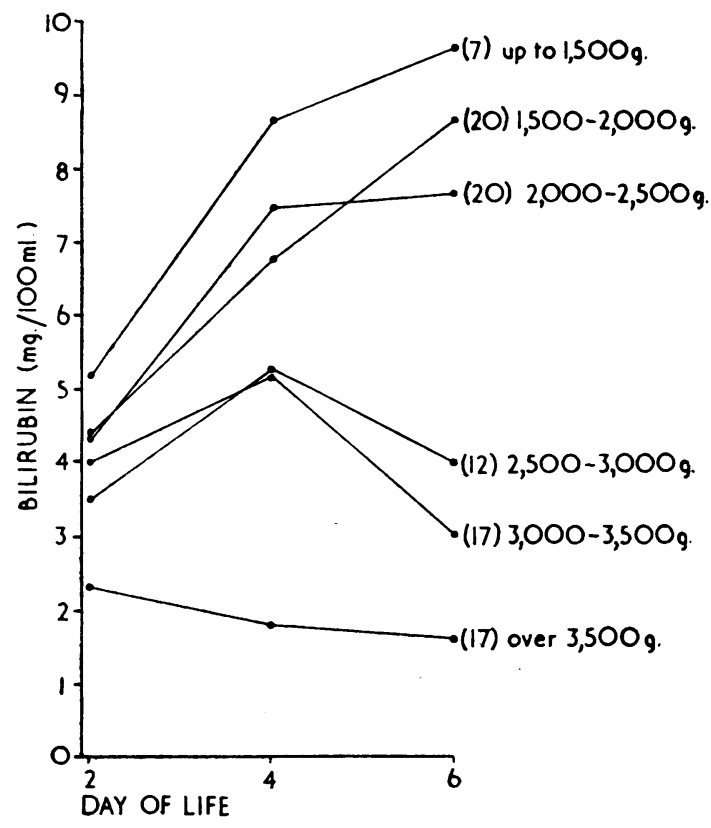

FIG. 1.-Mean bilirubin levels (indirect reacting) in 47 full-term and 46 premature babies. Since Fig. 1 was submitted comparative studies have been done on premature babies who received no vitamin $K$. and show generally lower curves for each weight group.

seen that the less the baby's weight at birth, the higher the post-natal bilirubinaemia and the later the peak. In babies weighing less than $2,000 \mathrm{~g}$. at birth, the serum bilirubin is still rising on the sixth day of life, the day when kernicterus most commonly develops.

It appeared from these findings that all babies

* The figures given in this paper refer only to indirect reacting bilirubin. 
with a serum bilirubin level above $18 \mathrm{mg}$. per $100 \mathrm{ml}$. developed kernicterus. This has, however, not been borne out by subsequent studies which are still in progress. To date, six premature babies have been encountered who did not develop kernicterus but in whom the serum bilirubin rose above $18 \mathrm{mg}$. per $100 \mathrm{ml}$.; nevertheless, $66 \%$ of those in whom the serum bilirubin rose above $18 \mathrm{mg}$. per $100 \mathrm{ml}$. have developed kernicterus.

\section{Discussion}

Although kernicterus has only recently been observed to be a hazard of prematurity, we do not think that it is necessarily a new disease in prematures, and this for two reasons. First, we have seen children with choreo-athetosis and a perceptive deafness who were deeply jaundiced in infancy, who were born prematurely and in whom no evidence of either $\mathrm{Rh}$ isoimmunization or of $\mathrm{ABO}$ incompatibility between the child and mother was found. Some of these probably had kernicterus of prematurity. Similar cases are to be found in surveys of children with cerebral palsy (Asher and Schonell, 1950). Secondly, we have noticed, over a number of years, a small group of prematures who survive the first few critical hours of life only to die unexpectedly towards the end of the first week. These children in the past were labelled 'late cerebrals'. Since 1945, necropsies have been performed by Dr. H. S. Baar on the majority of the premature babies in these units; it is only since 1945 that kernicterus has been recognized in this group of cases (Baar, 1945). The first few were diagnosed at necropsy; the majority are now diagnosed before death, and confirmed at necropsy.

To suggest that the disease is not new does not imply that its incidence may not have increased. With the greater care now devoted to prematures it is possible that more survive long enough to develop kernicterus. In addition, the introduction of new methods of treatment, e.g., vitamin $\mathrm{K}$ for haemorrhagic disease in the newborn, may have led unwittingly to an increase in its incidence. It is, nevertheless, not encountered frequently. The highest yearly incidence in any of the premature baby units in Birmingham was $4.1 \%$ of all admissions, and this unit admits routinely only the more immature prematures, those weighing less than $2,000 \mathrm{~g}$. at birth. It has been found in only $6 \%$ of prematures at necropsy; its incidence in survivors has been very much less, namely $0.8 \%$.

The most important predisposing factor appears to be immaturity, as evidenced by the weight of the baby at birth, and by the period of gestation, because the incidence of the disorder increases considerably as birth weight and period of gestation decrease; it is ten times more common, for example, in prematures delivered before the 30th week than in those delivered after the 36th. The higher incidence of the disease in males also underlines the importance of immaturity, for of two babies with the same weight at birth, the male is the more immature. (The female weighs less on average than the male at corresponding periods of gestation.) The rarity with which the disease, in our practice, is associated with toxaemia in the mother also confirms the importance of immaturity, for though babies of toxaemic mothers tend to be underweight and often marasmic, they are relatively mature, the majority being delivered after the 36th week, when, as we have already shown, kernicterus is unusual.

Although immaturity seems the most important predisposing factor, some post-natal conditions are encountered more frequently in babies later developing kernicterus than in controls (Table 9), e.g., jaundice, marked atelectasis, cyanotic attacks, haemorrhagic diatheses, subnormal temperatures and asphyxia at birth. It is possible that these complications may contribute to the development of kernicterus; on the other hand they may only be other evidence of immaturity.

Govan and Scott (1953) have suggested that the prime cause of the cerebral damage in prematures with kernicterus is anoxia, and that this occurs at birth. An analysis of our material also suggests that anoxia may be a predisposing factor, but the anoxia in our cases was not always due to asphyxia at the time of delivery; in some it was ante-partum, due to premature separation of the placenta, while in others it was post-natal and due to marked atelectasis. Our finding that the second of the twins was more frequently affected than the first also suggests that asphyxia may play a part. Anoxia, however, was not invariable.

In haemolytic disease of the newborn, the incidence of kernicterus has been shown to be related to the level of serum bilirubin. Hsia, Allen, Gellis and Diamond (1952), estimating the total serum bilirubin, not merely the indirect reacting, found that kernicterus commonly occurred when the serum bilirubin rose above $30 \mathrm{mg}$. \%, but that it did not do so if the serum bilirubin was kept below $20 \mathrm{mg}$. \% (Hsia, 1954). Our studies in prematures also show that kernicterus occurs most commonly when the serum bilirubin rises to unusually high levels, even though there is not a critical level above which all babies develop kernicterus. This being so, it is reasonable to assume that any condition which interferes with liver function (and it 
is possible that anoxia and infection may do this), or which increases red cell destruction, will tend, if liver function is already immature, to cause a rise in the indirect reacting serum bilirubin, and, pari passu, in the incidence of kernicterus.

Allison (1955) has recently shown that vitamin K, in the form of 'synkavit', if given intramuscularly to vitamin E-deficient rats, will cause a severe haemolytic anaemia. Moore and Sharman (1955) have confirmed his findings and have also noted that different vitamin $K$ analogues have, in this respect, varying degrees of toxicity; 'synkavit', the preparation used in the premature units under investigation in Birmingham, was found by them to be toxic. That 'synkavit' may be a precipitating factor is also suggested by the experience of Laurance (1955). A review of our practice tends to confirm this, for the incidence of kernicterus has been consistently higher in unit $C$, which has used a consistently higher dosage. The incidence rose fourfold in unit $S$ when the dose of vitamin $K$ was increased in 1953. In both units, when one of twins developed kernicterus it was always the twin who had received more vitamin $\mathbf{K}$ who developed this complication. On the other hand, and this suggests that vitamin $\mathrm{K}$ therapy is not of over-riding importance, in four instances both twins were given the same amount of vitamin $\mathrm{K}$ and yet only one twin developed kernicterus (the weights, on average of the twins, affected and unaffected, were the same). Moreover, no indirect evidence of any haemolytic process has been obtained as might have been expected had vitamin $\mathrm{K}$ caused a haemolysis; the babies who developed kernicterus were not anaemic when they developed kernicterus, and in only two of the survivors did the haemoglobin eventually fall below $8.6 \mathrm{~g} . \%$. Nevertheless, it is possible that vitamin $\mathrm{K}$ contributes to the development of kernicterus, and in our units the dose is now restricted to one injection on the first day of life, as this has been shown to be adequate for the prevention of haemorrhagic disease (Gordon, 1949). This alteration in treatment has not eradicated kernicterus; one baby who was given only $2 \mathrm{mg}$. of 'synkavit' and another who received none have subsequently developed kernicterus.

Hepatic immaturity would appear to be the most important underlying factor in the development of kernicterus in prematures. Liver function is so immature in these babies that the indirect-reacting bilirubin accumulates in the blood, rising to dangerously high levels. It is possible that substitution therapy with a suitable liver extract might enable the liver to metabolize and excrete bilirubin more efficiently, but, in the light of our present knowledge the only certain way of eliminating kernicterus in prematures would appear to be by an exchange transfusion whenever the bilirubin threatens to reach the danger level; by this means the indirect-reacting bilirubin is removed from the body at a time when the liver is unable to do this on its own account.

\section{Summary and Conclusions}

Details have been given of the mode of onset, mortality and signs in survivors of 60 babies developing kernicterus associated with prematurity only.

Ante-natal, natal and post-natal factors which might have contributed to the development of kernicterus in these cases have been analysed, and a comparison has been made with 60 controls and with all premature babies admitted to the units under investigation.

Bilirubin levels have been studied in 12 premature babies with kernicterus and in a series of normals.

The incidence of kernicterus and its mortality were greatest in those who were most immature at birth, as evidenced by the birth weight and period of gestation.

The post-natal bilirubinaemia was also greatest in the babies who were most immature, as evidenced by the weight at birth.

In 10 of 12 babies with kernicterus bilirubin levels rose above $18 \mathrm{mg}$. \%. Levels of this order were uncommon in unaffected prematures, but they were encountered in six instances.

A history of anoxia and of excessive therapy with vitamin $\mathrm{K}$ ('synkavit') was more common in babies developing kernicterus than in controls, and may have contributed to the development of this complication, but the most important underlying aetiological factor appeared to be the immaturity of the infant, and, more particularly, the immaturity of the liver.

We are very grateful to Dr. H. S. Baar for his help and advice, and for his post-mortem studies; to Dr. W. Weiner for the serological studies; to Dr. A. H. Henley for technical assistance; and to the sisters and nursing staff of the premature baby units, without whose help this work could not have been undertaken.

REFERENCES

Aidin, R., Corner, B. and Tovey, G. (1950). Lancet, 1, 1153.

Allison, A. C. (1955). Ibid., 1, 669 .

Asher, P. and Schonell, F. E. (1950). Archives of Disease in Childhood, 25, 360 .

Baar, H. S. (1945). Austrian med. Bull. Special issue (Oct.-Nov.), p. 1.

Gerrard, J. (1952). Brain, 75, 526.

Gordon, R. G. (1949). Lancet, 1, 692.

Govan, A. D. T. and Scott, J. M. (1953). Ibid., 1, 611

Hsia, D. Y. Y. (1954). Rep. 7th M. and R. Pediatric Research Conference, p. 30

Allen, F. H., Gellis, S. S. and Diamond, L. K. (1952). New Engl. J. Med., 247, 668

Laurance, B. (1955). Lancet, 1, 819

Malloy, H. T. and Evelyn, K. A. (1937). J. biol. Chem., 119, 481

Moore, T. and Sharman, I. M. (1955). Lancet, 1, 819.

Zuelzer, W. W. and Mudgett, R. T. (1950). Pediatrics, 6, 452. 